\title{
Dykes and deformation in the Ikertôq zone of the Nagssugtoqidian at Søndre Strømfjord Airport, West Greenland - a discussion
}

\author{
F. KALSBEEK AND H. P. ZECK
}

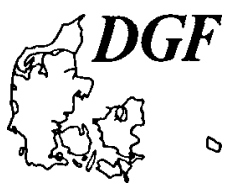

\begin{abstract}
Kalsbeek, F. and Zeck, H. P.: Dykes and deformation in the Ikertôq zone of the Nagssugtoqidian at Søndre Strømfjord Airport, West Greenland - a discussion. Bull. geol. Soc. Denmark, vol. 34, pp. 213-217, Copenhagen, December, 20th, 1985. https://doi.org/10.37570/bgsd-1985-34-17

$\mathrm{Rb}-\mathrm{Sr}$ isotope evidence indicates that deformation in the border zone between the Archaean craton and the Nagssugtoqidian mobile belt in West Greenland took place both during the late Archaean (at ca. 2600 $\mathrm{Ma}$ ) and during the Proterozoic Nagssugtoqidian orogeny (1850-1600 Ma). The structure (fabric) of the rocks is the combined effect of these two episodes of deformation.
\end{abstract}

Feiko Kalsbeek, Grønlands Geologiske Undersøgelse, Øster Voldgade 10, 1350 Copenhagen K, Denmark. Hubert P. Zeck, Institut for Petrologi, Københavns Universitet, Øster Voldgade 10, Copenhagen K, Denmark. April 5th, 1985.

The southern margin of the Nagssugtoqidian mobile belt of West Greenland (Escher, Sørensen \& Zeck, 1976) consists of reworked, strongly sheared material of the Archaean craton to the south. The boundary between the Nagssugtoqidian mobile belt and the craton runs through the Søndre Strømfjord area and is spectacularly revealed by a swarm of basic dykes, the 'Kangâmiut dykes', which form well preserved doleritic to gabbroic intrusive bodies in the craton, but become strongly attenuated and boudinaged amphibolite layers in the Nagssugtoqidian gneisses to the north (Ramberg, 1948; Escher, Escher \& Watterson, 1975; Escher et al., 1976; Zeck \& Kalsbeek, 1981). The simplest evolutionary model for the geology of the area (Ramberg, 1948) would therefore consist of : (1) Formation of the Archaean rocks (at ca. $2950 \mathrm{Ma}$; Kalsbeek \& Zeck, 1978a); (2) Intrusion of the Kangâmiut dykes (at ca. $1950 \mathrm{Ma}$; Kalsbeek, Bridgwater \& Zeck, 1978); and (3) Nagssugtoqidian deformation and metamorphism (ca. 1850-1600 Ma; e.g. Larsen \& Møller, 1968). This simple model had to be revised, however, when it was found that, locally, undeformed and unmetamorphosed Kangâmiut dykes had been intruded into already existing shear zones (Bridgwater, Escher, Nash \& Watterson, 1973), and it was then believed that the intrusion of the Kangâmiut dyke swarm took place during, or just after the first Nagssugtoqidian ENE shear movements (Bridgwater et al. op. cit.). The Nagssugtoqidian orogeny was therefore subdivided into two main phases: Nag. 1, pre- to syn-Kangâmiut dyke intrusion, and Nag. 2, post-dyke intrusion. Subsequent $\mathrm{Rb}-\mathrm{Sr}$ isotope evidence, however, indicated that at least some of the shear zones are considerably older than the intrusion of the Kangâmiut dykes, and it was concluded that the Nag. 1 shear zones probably formed during the late Archaean (Kalsbeek \& Zeck, 1978a; Hickman, 1979; Pedersen \& Bridgwater, 1979), and correlate with late Archaean ENE shear zones found elsewhere in the Archaean craton.

In a recent contribution to this journal, Van der Molen (1984) presented the results of a study of the relationships between structures in the Nagssugtoqidian gneisses in the Søndre Strømfjord region and the deformation of the Kangâmiut dykes. In this paper Van der Molen questions our $\mathrm{Rb}-\mathrm{Sr}$ isotope evidence that part of the metamorphic layering in the Nagssugtoqidian gneisses is of late Archaean age, and that the Nag. 1 shear zones in the Archaean gneisses just south of the Nagssugtoqidian border were formed during the late Archaean. Van der Molen suggests that the "presently observed fabric of the gneisses generally postdates intrusion of the 
dykes" (p. 105). In this paper we discuss part of our Rb-Sr data in the light of Van der Molen's paper. While not denying the profound influence of post-dyke deformation, we maintain that important elements of the rock fabric are of Archaean age.

\section{Nag. 1 shear zones south of the Nagssugtoqidian border}

The Kangâmiut dykes in the northernmost part of the Archaean craton are often bordered on both sides by a zone of strongly sheared gneisses, which are much lighter in colour that the buffbrown granulite facies gneisses further away from the dykes (Escher et al., 1976, fig. 82). More rarely, minor shear zones occur without associated dykes, and some dykes are in contact with unsheared gneisses. In detail, the dykes are locally clearly discordant to the well developed foliation in the sheared gneisses (Kalsbeek \& Zeck, 1978b).

Some of the shear zones are chemically distinct from the Archaean hypersthene gneisses from which they were formed. One inportant difference is a marked increase in $R b$ in the sheared gneisses relative to the Archaean parent, bearing witness to the introduction of $\mathrm{Rb}$ during shearing and retrogression of the rock, a phenomenon well known from shear zones elsewhere (e.g. Pedersen \& Bridgwater, 1979). Such introduction of $\mathrm{Rb}$ can be dated by isotopic methods.

Table 1. Rb-Sr isotope data for scattered samples of the Nagssugtoqidian gneisses in the Søndre Strømfjord area.

\begin{tabular}{lrlll}
\hline Sample & $\mathrm{Rb}$ & $\mathrm{Sr}$ & ${ }^{87} \mathrm{Sr} /{ }^{86} \mathrm{Sr}$ & ${ }^{87} \mathrm{Rb} /{ }^{86} \mathrm{Sr}$ \\
\hline $121801^{*}$ & 87 & 165 & 0.7601 & 1.492 \\
$123052^{*}$ & 123 & 152 & 0.7911 & 2.290 \\
$123054^{*}$ & 141 & 210 & 0.7763 & 1.954 \\
122902 & 47 & 520 & 0.7138 & 0.255 \\
122925 & 119 & 400 & 0.7294 & 0.835 \\
122946 & 67 & 382 & 0.7205 & 0.487 \\
122962 & 85 & 375 & 0.7273 & 0.629 \\
\hline
\end{tabular}

The samples marked with an asterisk come from Nag. 1 shear zones in the Archaean craton; the other samples are from north of the craton. $\mathrm{Rb}$ and $\mathrm{Sr}$ (ppm) by XRF (Institut for Petrologi); precisions \pm ca. $1 \mathrm{ppm}$ for $\mathrm{Rb}$ and $2 \%$, relative, for $\mathrm{Sr} .{ }^{87} \mathrm{Sr} /{ }^{86} \mathrm{Sr}$ (Institut for Petrologi), normalised and relative to the Eimer and $\mathrm{Amend} \mathrm{SrCO}_{3}$ standard $=0.7080$, is precise to ca. 0.0002 (lo), and ${ }^{87} \mathrm{Rb} /{ }^{86} \mathrm{Sr}$ to ca. $1 \%(1 \sigma)$.

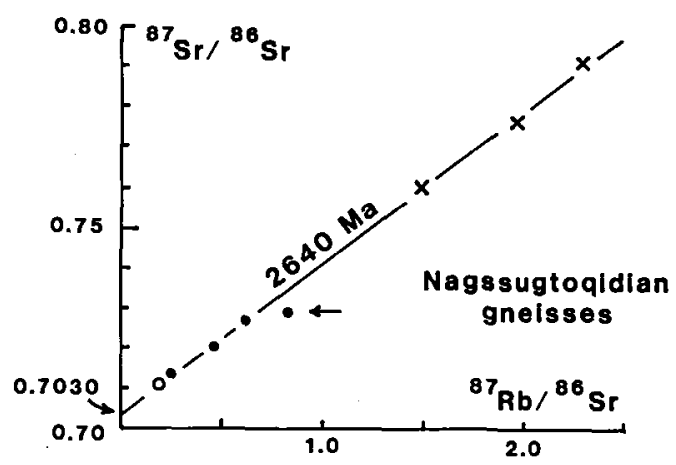

Fig. 1. Rb-Sr isochron diagram for scattered samples of the Nagssugtoqidian gneisses in the Søndre Strømfjord area. Dots: samples from north of the Archaean craton. Crosses: samples from shear zones within the Archaean craton. The sample indicated with an arrow was not used in the age calculation. The circle represents the estimated mean ${ }^{87} \mathrm{Rb} /{ }^{86} \mathrm{Sr}$ and ${ }^{87} \mathrm{Sr} /{ }^{86} \mathrm{Sr}$ values of the Archaean hypersthene gneisses in the area for comparison.

We have obtained $\mathrm{Rb}-\mathrm{Sr}$ isotope data on seven samples of Nagssugtoqidian gneisses from widely scattered localities (Table 1, fig. 1). Six of these define an isochron with an age of $2640 \pm 50 \mathrm{Ma}$ $\left(\gamma^{87} \mathrm{Rb}=1.42 \times 10^{-11} \mathrm{a}^{-1} ;\right.$ errors at the $95 \%$ level of confidence) and initial ${ }^{87} \mathrm{Sr} /{ }^{86} \mathrm{Sr}$ ratio 0.7030 \pm 0.0005 (Kalsbeek \& Zeck, 1978a). The three samples with highest $\mathrm{Rb} / \mathrm{Sr}$ ratios are from Nag. 1 shear zones in Archaean gneisses, and the high $\mathrm{Rb} / \mathrm{Sr}$ ratios of these samples $\left({ }^{87} \mathrm{Rb} /{ }^{86} \mathrm{Sr} 1.5-2.3\right)$ relative to the surrounding hypersthene gneisses $\left({ }^{87} \mathrm{Rb} /{ }^{86} \mathrm{Sr}\right.$ generally $<0.5$, fig. 1$)$ is apparently due to the $\mathrm{Rb}$ enrichment during shearing mentioned above. The isochron age thus effectively dates the $\mathrm{Rb}$ enrichment and thus the shear zone formation. The emplacement of the Kangâmiut dykes took place at ca. $1950 \mathrm{Ma}$ (Kalsbeek et al., 1978), and we concluded therefore, perhaps not surprisingly, that the dykes had been emplaced into significantly older shear zones.

Van der Molen states that "inspection of the clearly presented field evidence (Kalsbeek \& Zeck, 1978b, figs 16 and 17) favours the less complex interpretation that the dykes intruded while the shear zone developed" (p. 105-106). We feel that our field evidence is compatible with both hypotheses. However, a more detailed discussion of the merits of these structural relations is rather academic because the isotopic evidence, given above, clearly excludes Van der Molen's 'less complex' interpretation. In that respect the structures in question may serve as an eminent exam- 
ple that structures in high grade complexes cannot always be taken at face value, and that careful interpretation of further petrological/ geochemical investigations may reveal their proper nature.

\section{Nagssugtoqidian gneisses near Søndre Strømfjord Airport}

In an attempt to date the Nag. 2 deformation we analysed a number of samples from a large banded gneiss block from a small quarry near Søndre Strømfjord Airport, where Nag. 2 (postdyke) deformation is very clearly in evidence. The results were surprising: the samples scatter along a ca. $2600 \mathrm{Ma}$ isochron (fig. 2A, Table 2) and give no information on the timing of Nag. 2 .

Also here it is possible to give an interpretation of the (approximate) age obtained: three of the samples (nos. 3-5, fig. 2B) are from a ca. $30 \mathrm{~cm}$ thick layer of leucocratic gneiss, bordered by

Fig. 2A. $\mathrm{Rb}$-Sr isochron diagram for successive layers (samples 1-9, fig. 2B) from a banded gneiss at Søndre Strømfjord Airport. Samples 1-4 are from a leucocratic layer in the gneiss and from the bordering more melanocratic rock (see the text) and are numbered in the diagram. B. Chemical composition of successive layers of the same banded gneiss (samples 233721-733, see Table 2, indicated by numbers $1-13$ along the top of the diagram). Nos. 3-5 are from a leucocratic biotite gneiss layer (see the text) and nos. 10-13 are from an amphibolite layer. The latter are not shown in the isochron diagram of fig. $2 \mathrm{~A}$. FeO*: total iron calculated as $\mathrm{FeO}$.
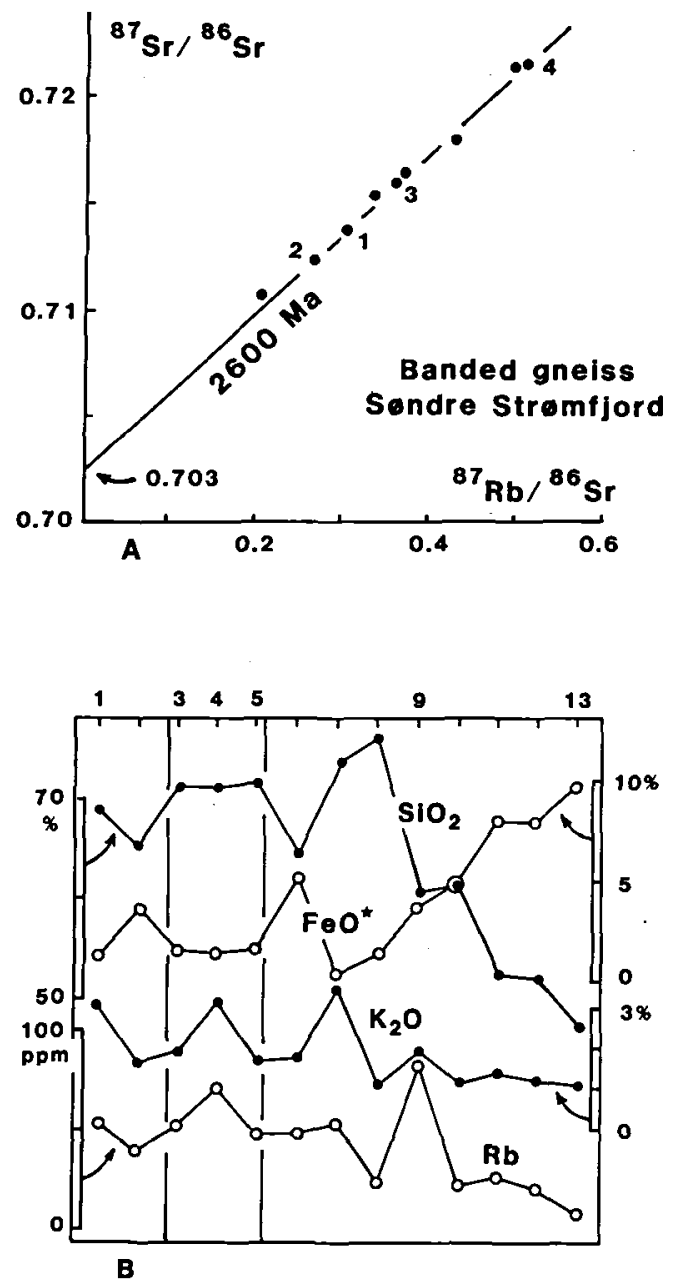

Table 2. Chemical and Rb-Sr isotope data for samples from a banded gneiss at Søndre Strømfjord.

\begin{tabular}{|c|c|c|c|c|c|c|c|c|c|}
\hline Sample & $\mathrm{SiO}_{2}$ & $\mathrm{Fe} 0^{*}$ & $\mathrm{MgO}$ & $\mathrm{CaO}$ & $\mathrm{K}_{2} \mathrm{O}$ & $\mathbf{R b}$ & $\mathrm{Sr}$ & ${ }^{87} \mathrm{Sr} f^{86} \mathrm{Sr}$ & ${ }^{87} \mathrm{Rb} /{ }^{86} \mathrm{Sr}$ \\
\hline 233721 & 68.91 & 1.39 & 0.76 & 3.21 & 2.97 & 54 & 519 & 0.7137 & 0.305 \\
\hline 722 & 65.38 & 3.76 & 1.96 & 4.49 & 1.44 & 40 & 434 & 0.7123 & 0.266 \\
\hline 723 & 71.54 & 1.59 & 0.73 & 2.90 & 1.73 & 52 & 419 & 0.7159 & 0.360 \\
\hline 724 & 71.44 & 1.51 & 0.53 & 2.37 & 3.06 & 72 & 406 & 0.7215 & 0.512 \\
\hline 725 & 71.76 & 1.72 & 0.68 & 2.91 & 1.52 & 48 & 412 & 0.7154 & 0.337 \\
\hline 726 & 64.37 & 5.24 & 2.78 & 4.76 & 1.62 & 50 & 335 & 0.7179 & 0.430 \\
\hline 727 & 73.56 & 0.56 & 0.10 & 2.19 & 3.37 & 55 & 431 & 0.7164 & 0.371 \\
\hline 728 & 75.95 & 1.47 & 0.88 & 2.91 & 0.84 & 23 & 317 & 0.7107 & 0.207 \\
\hline 729 & 60.43 & 3.77 & 2.23 & 4.44 & 1.88 & 86 & 516 & 0.7214 & 0.480 \\
\hline 730 & 61.55 & 5.01 & 4.05 & 6.22 & 1.06 & 24 & 320 & 0.7126 & 0.218 \\
\hline 731 & 52.28 & 8.08 & 7.79 & 8.90 & 1.37 & 29 & 176 & 0.7185 & 0.478 \\
\hline 732 & 52.07 & 7.96 & 7.09 & 9.20 & 1.21 & 24 & 206 & 0.7158 & 0.338 \\
\hline 733 & 47.09 & 9.88 & 9.50 & 11.74 & 1.05 & 10 & 101 & 0.7103 & 0.302 \\
\hline
\end{tabular}

Samples 233721-733 are from a single block of banded gneiss: 233721 striped hornblende-biotite gneiss, 722 dark hornblende-biotite gneiss, 723-725 leucocratic biotite gneiss, 726 biotite-rich gneiss, 727 coarse-grained white gneiss, 728 and 729 hornblende-biotite gneiss, 730-732 veined amphibolite, and 733 massive amphibolite. Major elements (weight \%) mainly by XRF (GGU). Fe0*: total iron calculated as Fe0. Rb, Sr (ppm) and isotopic ratios were measured at the Institut for Petrologi, precisions as indicated in Table 1. 
more melanocratic layers. This leucocratic layer is chemically very homogeneous for less mobile elements such as $\mathrm{Si}, \mathrm{Fe}$ and $\mathrm{Al}$ ( $\mathrm{Al}$ not shown in fig. 2B), but distinctly inhomogeneous for mobile elements such as $\mathrm{K}$ and $\mathrm{Rb}$. Apparently, the margins of the white layer have lost part of their $\mathrm{K}$ and $\mathrm{Rb}$ to the adjoining less felsic layers. Replacement of hornblende by biotite in the more melanocratic gneisses bordering the leucocratic layer confirms this, and shows that the metasomatic exchange took place during the shearing and metamorphism of the rock. Samples 1-4 of the banded gneiss block, which come from the centre and the rim of the leucocratic layer and from the bordering darker gneiss, and between which exchange of $\mathrm{Rb}$ is therefore evident, plot within analytical precision on the $2600 \mathrm{Ma}$ lineof-best-fit in fig. 2A, and give an age of 2590 $\pm 100 \mathrm{Ma}$. The isochron therefore dates the time of $\mathrm{Rb}$ exchange between neighbouring layers in the banded gneiss. The general scatter of the data points with respect to the isochron is readily explained by later (Nag. 2) disturbance of the $\mathrm{Rb}-\mathrm{Sr}$ isotope systems. Mobility of $\mathrm{Rb}$ and $\mathrm{Sr}$ during Nag. 2 must have been restricted, however, in this case, since major changes in the $\mathrm{Rb} / \mathrm{Sr}$ ratios during Nag. 2 would have upset the linear array of data points in the isochron diagram.

The same distinct banding on centimetre to decimetre scale seen in the gneiss block analysed is also commonly observed elsewhere in outcrops of Nagssugtoqidian gneisses, and is an important structural element of the rocks. This layering is apparently inherited from the Archaean parents of the gneisses, and the Kangâmiut dykes are locally clearly discordant to this banding (fig. 3).

Strong post-dyke deformation, both of the dykes themselves (fig. 3) and the country gneisses, is everywhere in evidence. Nobody who has seen the beautiful outcrops of deformed gneisses with enclosed dyke remnants in the

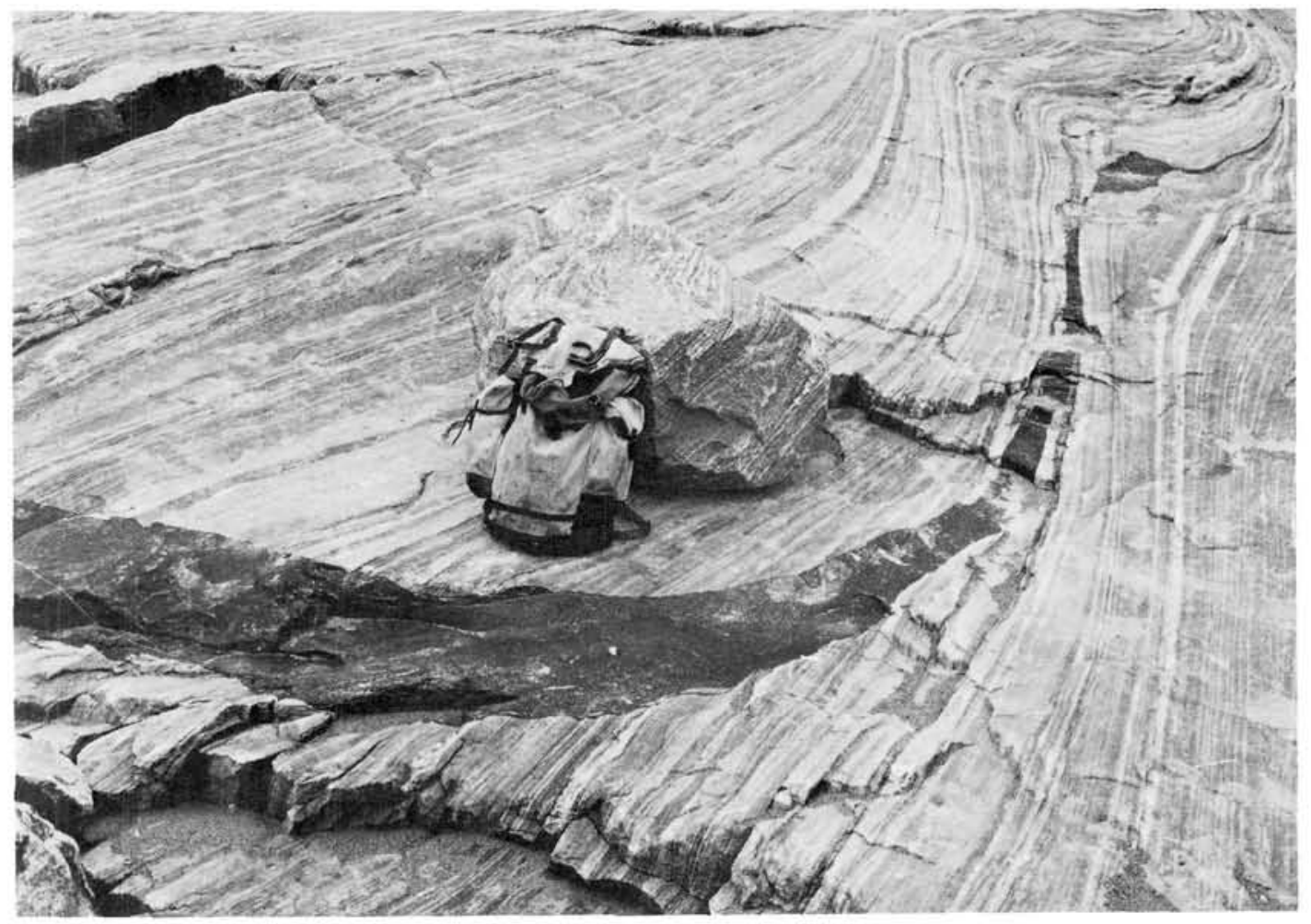

Fig. 3. Thin Kangâmiut dyke cutting the layering of the gneisses near the Inland Ice, NE of Søndre Strømfjord Airport. Isotopic evidence discussed in this paper indicates that the layering of the gneisses resulted from Archaean deformation and metamorphism. Deformation of the dyke (and renewed deformation of the surrounding gneisses) took place during the Proterozoic Nagssugtoqidian orogeny. Photograph by Margrethe Watt. 
Søndre Strømfjord area (Escher et al. 1976, figs 77,78 and 86) can disagree with this. Van der Molen gives the impression that we attach little importance to this post-dyke deformation. This is not the case. The quotation from Kalsbeek (1979) that "the strong shearing and metamorphism of the rocks did not take place during Nag-2" is incorrect. The text in Kalsbeek (1979) reads "the strong shearing and metamorphism of the rocks dated did not take place during Nag. 2", and relates specifically to the banded gneiss block studied.

Acknowledgements. The laboratories for isotope geology and $\mathrm{X}$-ray fluorescence spectrometry at the Institute of Petrology, Copenhagen University, where the samples have been analysed, are supported by the Danish Natural Science Research Council (SNF). We thank A. K. Higgins for valuable comments on the manuscript. Publication of this paper was permitted by the Director of the Geological Survey of Greenland.

\section{Dansk sammendrag}

Den sydlige randzone af det 'Nagssugtoqidiske mobile balte' i Vestgrønland består af stærkt deformerede Arkæiske bjergarter. Lignende stærkt deformerede bjergarter forekommer også som smalle zoner i det 'Arkæiske skjold' lige syd for gransen med det Nagssugtoqidiske mobile bælte. Proterozoiske (ca. 1950 millioner år) basiske gange - 'Kangâmiut gangene' - forekommer som velbevarede intrusive legemer i de udeformerede bjergarter indenfor det Arkæiske skjold, men er oftest stærkt deformerede i de Nagssugtoqidiske gnejser mod nord og $i$ de smalle deformationszoner $i$ skjoldet. Det var derfor narliggende at antage, at dannelsen af disse deformationszoner og deformationen af gnejserne $i$ det Nagssugtoqidiske mobile bælte havde fundet sted efter intrusionen af Kangâmiut gangene. Rb-Sr aldersbestemmelser (fig. 1 og 2), sammenholdt med kemiske analyser af de pågzldende bjergarter, viser dog, at denne antagelse ikke er korrekt. En vigtig deformationsfase fandt sted allerede i senarkxisk tid, for ca. 2600 millioner år siden, og en del af Kangâmiut gangene blev intruderet i bjergarter, der var deformeret under denne tidlige deformationsfase. Senere, for 1850-1600 millioner år siden, blev selve gangene deformeret og metamorfoseret. Samtidig gennemgik de omgivende gnejser fornyet deformation. Figur 3 viser bjergarternes udviklingshistorie i en nøddeskal: en tynd Kangâmiut gang ses intruderet diskordant i (i forvejen) stærkt deformerede, båndede Nagssugtoqidiske gnejser. Langere mod højre i fi- guren er gangen selv stærkt deformeret, sammen med de omgivende gnejser. Strukturerne i de Nagssugtoqidiske gnejser er derfor resultatet af to vigtige deformationsfaser, hvoraf den første er ca. 800 millioner år ældre end den anden.

\section{References}

Bridgwater, D., Escher, A., Nash, D. F. \& Watterson, J. 1973: Investigations on the Nagssugtoqidian boundary between Holsteinsborg and Kangâmiut, central West Greenland. Rapp. Gronlands geol. Unders. 55, 22-25.

Escher, A., Escher, J. C. \& Watterson, J. 1975: The reorientation of the Kangâmiut dyke swarm, West Greenland. Can. J. Earth Sci. 12, 158-173.

Escher, A., Sørensen, K. \& Zeck, H. P. 1976: Nagssugtoqidian mobile belt in West Greenland. In Escher, A. and Watt, W. S. (eds.), Geology of Greenland, 77-95. Copenhagen: Geol. Surv. Greenland.

Hickman, M. H. 1979: A Rb-Sr age and isotope study of the Ikertôk, Nordre Strømfjord, and Evighedsfjord shear belts, West Greenland - outline and preliminary results. Rapp. Gronlands geol. Unders. 89, 125-128.

Kalsbeek, F. 1979: Rb-Sr isotope evidence on the age of the Nagssugtoqidian orogeny in West Greenland, with remarks on the use of the term 'Nagssugtoqidian'. Rapp. Grønlands geol. Unders. 89, 129-131.

Kalsbeek, F. \& Zeck, H. P. 1978a: Preliminary Rb-Sr wholerock data for Archaean and Nagssugtoqidian rocks from the Søndre Strømfjord area, West Greenland. Rapp. Grønlands geol. Unders. 90, 129-134.

Kalsbeek, F. \& Zeck, H. P. 1978b: Nassugtoqidian deformation and Kangâmiut dyke intrusion in the Søndre Strømfjord area, West Greenland. Rapp. Grønlands geol. Unders. 90, 42-45.

Kalsbeek, F., Bridgwater, D. \& Zeck, H. P. 1978: A $1950 \pm 60$ Ma Rb-St whole-rock isochron age from two Kangâmiut dykes and the timing of the Nagssugtoqidian (Hudsonian) orogeny in West Greenland. Can. J. Earth Sci. 15, 11221128.

Larsen, O. \& Møller, J. 1968: Potassium-argon age studies in West Greenland. Can J. Earth Sci. 5, 683-691.

Pedersen, S. \& Bridgwater, D. 1979: Isotopic re-equilibration of $\mathrm{Rb}-\mathrm{Sr}$ whole rock systems during reworking of Archaean gneisses in the Nagssugtoqidian mobile belt, East Greenland. Rapp. Gronlands geol. Unders. 89, 133-146.

Ramberg, H. 1948: On the petrogenesis of the gneiss complexes between Sukkertoppen and Christianshaab, West Greenland. Meddr dansk geol. Foren. 11, 312-327.

Van der Molen, I. 1984: Dykes and deformation in the Ikertôq zone of the Nagssugtoqidian at Søndre Strømfjord Airport, West Greenland. Bull. geol. Soc. Denmark 32, 101106.

Zeck, H. P. \& Kalsbeek, F. 1981: Geochemistry of amphibolite facies metamorphism of a suite of basic dykes, Precambrian basement, Greenland. Chem. Erde 40, 1-22. 